\title{
Monitoring Vegetation Coverage and Biomass Using Landsat Thematic Mapper 5 Images in a Foothill Artemisia-Ephemeral Rangeland of Uzbekistan
}

\author{
Mahmud A. Muminov',2,3, Muhtor G. Nosirov ${ }^{3}$, Tashpulot F. Rajabov ${ }^{3}$, Tolibjon Kh. Mukimov4, \\ Haitou Liu' ${ }^{1,2}$, Jie Meng1,2, Caihong Li' ${ }^{1}$, Liyue Guo ${ }^{1,2}$, Cheng Da1,2, Gaoming Jiang1*
}

\author{
${ }^{1}$ State Key Laboratory of Vegetation and Environmental Change, Institute of Botany, The Chinese Academy of Sciences, Beijing, China \\ ${ }^{2}$ University of the Chinese Academy of Sciences, Beijing, China \\ ${ }^{3}$ Laboratory of Environmental Problems, Samarkand State University, Samarkand, Uzbekistan \\ ${ }^{4}$ Uzbek Research Institute of Karakul Sheep Breeding and Ecology of Deserts, Samarkand, Uzbekistan \\ Email: *jgm@ibcas.ac.cn
}

How to cite this paper: Muminov, M.A., Nosirov, M.G., Rajabov, T.F., Mukimov, T.Kh., Liu, H.T., Meng, J., Li, C.H., Guo, L.Y., Da, C. and Jiang, G.M. (2016) Monitoring Vegetation Coverage and Biomass Using Landsat Thematic Mapper 5 Images in a Foothill Artemisia-Ephemeral Rangeland of Uzbekistan. Open Journal of Ecolo$g y$, 6, 736-752.

http://dx.doi.org/10.4236/oje.2016.612066

Received: October 10, 2016

Accepted: November 26, 2016

Published: November 29, 2016

Copyright $\odot 2016$ by authors and Scientific Research Publishing Inc. This work is licensed under the Creative Commons Attribution International License (CC BY 4.0).

http://creativecommons.org/licenses/by/4.0/ (c) (i) Open Access

\begin{abstract}
This paper describes the capability of remote sensing in the monitoring of rangeland vegetation productivities and dynamics in the foothill areas of Uzbekistan, in order to enhance the sustainable utilization of natural resources. Seasonal productivity, including above-ground biomass, density, coverage, foliar chlorophyll, and carotene content, was measured for the Artemisia diffusa, the dominant species of the study area. The Normalized Difference Vegetation Index (NDVI), extracted from time-series Landsat TM5 satellite images, was used to obtain pertinent data regarding vegetation coverage and potential productivities. Seasonal precipitation was found to be a key factor in governing soil moisture in the semi-arid foothill rangelands, which directly influence the dynamics of plants and productivities. Precipitation and soil moisture determine the length of the plant growing season and further influence NDVI values. We found that time-series NDVI was significantly correlated with the seasonal green and total aboveground biomass of vegetation and coverage of Artemisia diffusa, soil moisture, and changeable nitrogen. We also found that the foliar chlorophylls of Artemisia diffusa was significantly correlated with the green above-ground biomass $(\mathrm{r}=0.44, P<0.05)$. The results can contribute to further monitoring of ecosystem health and habitat conditions using remote sensing (RS) as an accurate tool in large rangeland areas.
\end{abstract}

\section{Keywords}

Remote Sensing, NDVI, Biomass, Chlorophyll Content, Rangeland Degradation 


\section{Introduction}

In the past few decades, overgrazing and other anthropogenic impacts on rangeland have resulted in serious soil erosion and land degradation. As a result, the forage and husbandry industries have been poorly affected [1]. Such processes have become much more serious in the foothill areas of the rangeland in the Central Asian countries, in particular. Continuous and unplanned land use has further decreased the species diversity and biomass of the grassland ecosystem [2] [3]. Degradations of land [4] [5] and soil [6] are identified as the main stresses for the sustainability of rangeland around the world. Such a land use pattern would easily cause land degradation without planned grazing in the event of a population explosion [7] [8] [9]. However, it is difficult to evaluate the degree of degradation of the rangeland as well as the coverage and productivity of vegetation under conditions of intense human activity.

The growth of plants largely depends on the interaction between environmental factors. There are direct and indirect effects by seasonal climate change on the growth of plants. Good correlation with all measures of canopy structure and chemical composition supports the basis of economic theory [10]. The investment in the canopy chlorophyll, green leaf area, and biomass of leaves acts as a cost-conservative balance between components of the photosynthetic system [11]. Nevertheless, the effects of animal grazing might shift vegetation growth patterns. Few studies have been conducted on the vegetation dynamics and physiological variables of arid and semi-arid rangeland, including the consideration of a grazing gradient in continuous long-term monitoring.

Many scientists have recommended using particular indexes to identify the current status of plant health, and the most widely used index is the Normalized Difference Vegetation Index (NDVI) [12]. NDVI is calculated by the ratio $(\rho I R-\rho R) /(\rho I R+\rho R)$, where $\rho I R$ is the near-infrared reflectance and $\rho R$ is the reflectance in the red electromagnetic spectrum region. The green part of the leaf and its biomass show a high correlation with the NDVI [13]. Vegetation indexes are mainly derived from reflectance data in discrete red and near-infrared bands [14]. Green plants are sensitive to the reflection of absorption in the red $(0.63-0.69 \mu \mathrm{m})$ and infrared $(0.76-0.90 \mu \mathrm{m})$ spectrum. Therefore, both infrared and red spectra give us useful information about the vigor status of plants, such as canopy greenness, photosynthetic pigments, and physiological activity of vegetation. Furthermore, as direct indicators influencing plant growth, infrared and red spectra are widely used for evaluating large area vegetation growth patterns.

Remote sensing (RS) can reflect the seasonal physiological status of plants and, subsequently, elaborate on the eco-physiological bases of rangeland managing systems. Remote-sensing-based NDVI is widely applied in monitoring and assessing vegetation dynamics [5] [15] and above-ground net primary production (ANPP) [16] [17], mostly focusing on the long-term environmental and eco-physiological changes. The NDVI is positively correlated with rainfall in the arid and semi-arid regions [5] [18]. However, chain correlations of NDVI with seasonal climate, plant, and soil features have yet to be investigated rigorously. 
As long-term ground sampling and analysis may consume large amounts of time and labor, practical application remains challenging. We hypothesized that a chain correlation may exist between biological and environmental variables, as precipitation and soil moisture strongly govern vegetation growth, which is reflected by the NDVI [18]. Human activities, especially free-range and grazing, may disturb the relationship, so there is an urgent need to develop affordable and precise tools to monitor the vegetation coverage and productivity of the rangeland ecosystem in arid areas.

In this study, we have selected RS as a useful tool for monitoring and managing rangeland. RS data can serve as a means for assessing and monitoring rangeland productivity and the level of degradation. Moreover, it can be helpful in constructing a managing ecosystem model for restoring degraded areas and addressing ecosystem imbalance. Large sets of data on plant coverage and land use can be obtained by analyzing satellite images [19]. If the correlation among the NDVI and vegetation coverage, above-ground biomass, climate, and soil condition really exist, actual remote-sensingbased monitoring might prove very useful [20].

However, the estimation of land degradation largely relies on field sampling, and understanding the relationship between environmental and physiological factors remains difficult. The main aims of this study understand 1) the impact of environmental factors on plant growth and changes; 2) the different seasonal dependencies between climate and the NDVI, which are based on canopy greenness, including above-ground biomass, cover, content of foliar chlorophyll, and carotenoids; and 3) the relationship among seasonal precipitation, soil moisture, and the rangeland NDVI. This study will help decision makers assess the vegetation coverage and ecosystem productivity in arid and semi-arid rangeland, which are facing degradation problems.

\section{Materials and Methods}

\subsection{Study Area}

The area of study is the semi-arid Aktau foothill rangelands of Samarkand Province, Uzbekistan $\left(40^{\circ} 9^{\prime} \mathrm{N}, 66^{\circ} 39^{\prime} \mathrm{E}\right)$ shown in Figure 1. The type of landscape is characterized as low to high relief. The study area is $4300 \mathrm{~km}^{2}$, covering $9.5 \%$ of Uzbekistan territory. The altitude of the study area ranges from 500 to $1600 \mathrm{~m}$ above sea level [7]. The climate condition is quite varied owing to the diversity of the landscape. According to the climate classification, the Aktau ridge belongs to the continental subtropical climates of Asia [21]. The site is located in the peripheral part of the western Tian-Shan and in the interface with the Kyzyl Kum desert. Aktau Mountain experiences the impact of this desert, receiving strong warm air masses in the summer with temperatures reaching $30^{\circ} \mathrm{C}-35^{\circ} \mathrm{C}$ in the mountains and $42^{\circ} \mathrm{C}-43^{\circ} \mathrm{C}$ in the foothills (Figure 2).

In July, the average air temperature of mountain area is $24^{\circ} \mathrm{C}$, and the precipitation ranges from 350 to $400 \mathrm{~mm}$ [21]. Spring comes in late February or early March, and the fall begins in September, with the vegetation period being 260 - 270 days. The dominant soil type is light sierozem, with a heavy accumulation or stone deposition of gypseous layer [7]. The soil is mostly barren, with less than $1 \%$ organic matter. The forage capacity 
of the rangeland ranges from $300-700 \mathrm{~kg}$ of dry matter per hectare [7] [22], depending on the climatic conditions. During spring and summer, the land suffers from heavy grazing stress due to the free range of cattle and sheep. Although the stress decreases sharply from autumn to winter time, grazing on $A$. diffusa still continues. The human population and number of total livestock are 115,000 and 413,766 heads, respectively. Overgrazing is the most important influencing factor for land degradation.

\subsection{Vegetation}

Most of the study area is covered with $A$. diffusa during the entire year, while species like Iris songarica and Alhagi pseudalhagi are sparsely present; in the spring season, common sub-dominant ephemeroid species like Poa bulbosa, Carex pachystylis, Salsola spp, and Holosteum umbellatum are present. Other species such as Poa bulbosa, Carex pachystylis, and Salsola spp are also noted, covering 15\% - 20\% of Artemisia-ephemeral rangelands [7] [23]. In the foothills, some woody species vegetation, such as Pistaciavera spinosissima, Punica granatum, Atraphaxis spinosa, and Zygophyllum gontscharovii can also be found [7] [24]. As the northern slopes receive more precipitation, a green carpet composed of Carex pachystylis develops well. Species such as Festuca spp., viviparous P. bulbosa, Hordeum bulbosum, Stipa spp., Aegilop striuncialis, and Bromus

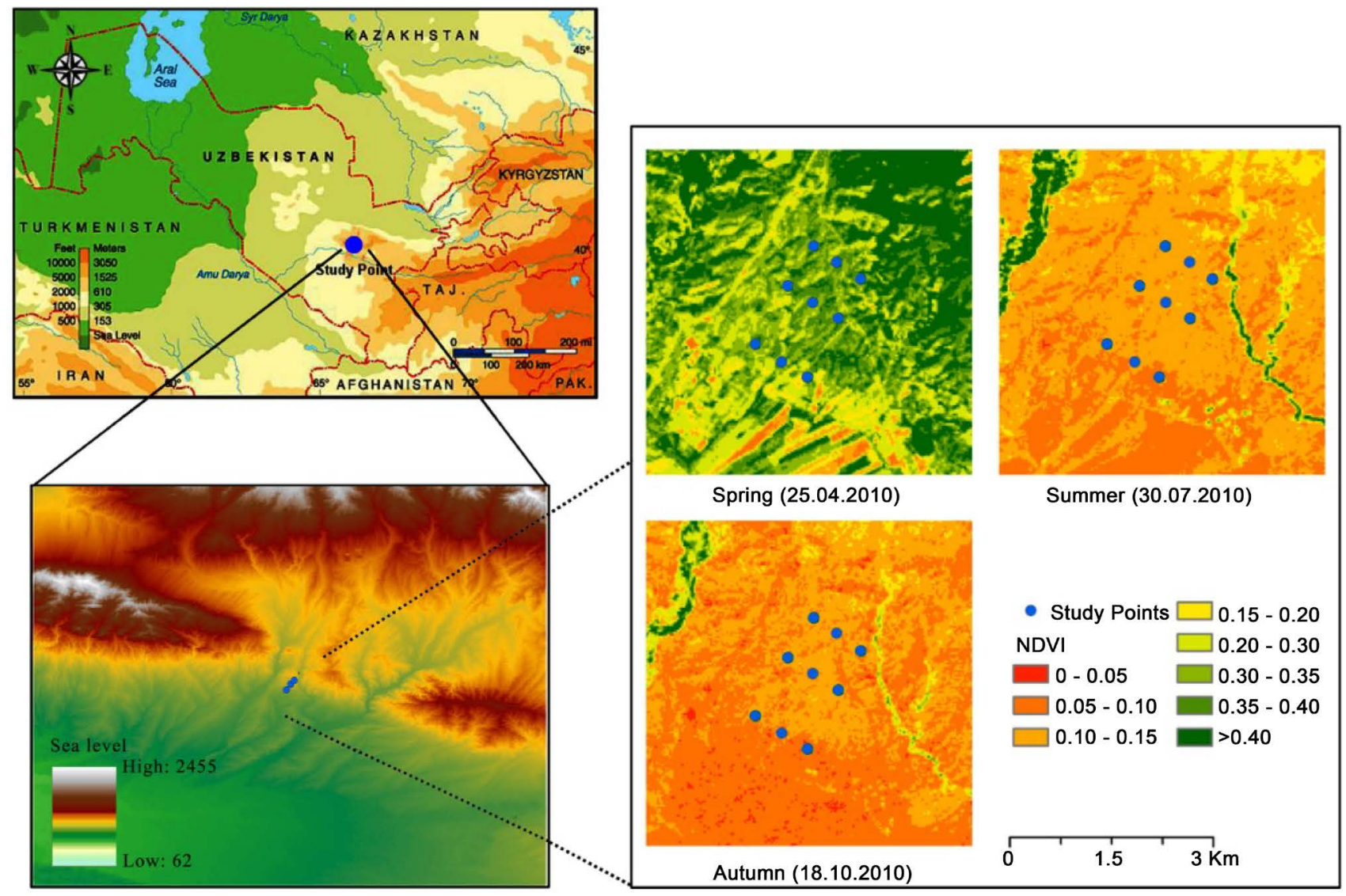

Figure 1. The landscape of the semi-arid Aktau foothill rangelands in Samarkand Province, Uzbekistan, with blue pentagram indicating for fixed sampling locations. 


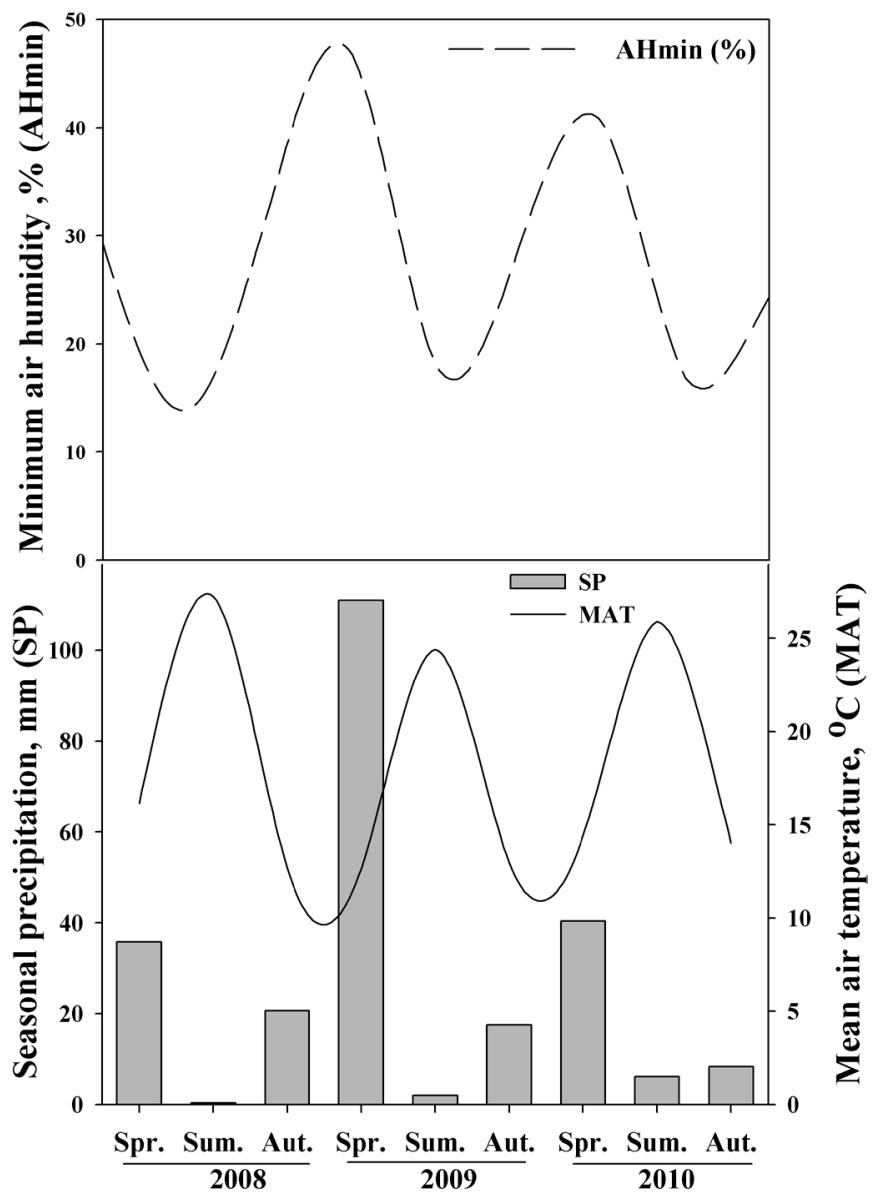

Figure 2. Seasonal dynamics of climate indicators during the plant growing seasons (from March to November) in 2008-2010. Seasonal precipitation, mm (SP); Minimumair humidity, \% (AHmin); Meanair temperature, ${ }^{\circ} \mathrm{C}(\mathrm{MAT})$

tectoim are common [7]. The dominant species in the study area is A. diffusa; therefore, in this study we have chosen this species for further detailed analysis.

\subsection{Meteorological and Soil Data Collection}

Climate data, including daily mean air temperature, minimum relative air humidity, and precipitation from 2008-2010, were obtained from the Kushrabad Meteorological Station in the Samarkand region. The station is located $5 \mathrm{~km}$ from the study area. Soil samples were collected monthly from the plot location (Table 1) to measure the soil moisture. Soils were sampled in every sample plot from $0-40 \mathrm{~cm}$ and were divided into two parts. The first part was used to measure the soil moisture, and the second part was used to measure the changeable mineral nitrogen in the soil. Soil moisture was determined through drying for 48 hours in a drying furnace. The nitrogen was determined by the Grandval-Lyazhu method, which is based on the interaction between nitrates and disulfofenol acid to form trinitrophenol (picric acid). An alkaline medium gives a yellow color due to the formation of trinitrophenol potassium in an amount equivalent to the nitrate content. The color intensity is measured by a photo-colorimeter [25]. 
Table 1. Locations of sampling sites.

\begin{tabular}{ccc}
\hline Sites & Repetitions & Latitude Longitude \\
\hline a-site & $1)$ & $40^{\circ} 857.14^{\prime \prime} \mathrm{N}, 66^{\circ} 38^{\prime} 36.36^{\prime \prime} \mathrm{E}$ \\
& $2)$ & $40^{\circ} 8^{\prime} 53.00^{\prime \prime} \mathrm{N}, 66^{\circ} 38^{\prime} 39.85^{\prime \prime} \mathrm{E}$ \\
& $40^{\circ} 8^{\prime} 50.04^{\prime \prime} \mathrm{N}, 66^{\circ} 38^{\prime} 51.61^{\prime \prime} \mathrm{E}$ \\
b-site & $40^{\circ} 9^{\prime} 23.56^{\prime \prime} \mathrm{N}, 66^{\circ} 39^{\prime} 10.01^{\prime \prime} \mathrm{E}$ \\
& $2)$ & $40^{\circ} 9^{\prime} 17.99^{\prime \prime} \mathrm{N}, 66^{\circ} 39^{\prime} 12.40^{\prime \prime} \mathrm{E}$ \\
& $40^{\circ} 9^{\prime} 14.02^{\prime \prime} \mathrm{N}, 66^{\circ} 39^{\prime} 26.69^{\prime \prime} \mathrm{E}$ \\
c-site & $40^{\circ} 9^{\prime} 41.28^{\prime \prime} \mathrm{N}, 66^{\circ} 39^{\prime} 23.21^{\prime \prime} \mathrm{E}$ \\
& $2)$ & $40^{\circ} 9^{\prime} 36.75^{\prime \prime} \mathrm{N}, 66^{\circ} 39^{\prime} 28.11^{\prime \prime} \mathrm{E}$ \\
& $3)$ & $40^{\circ} 9^{\prime} 31.78^{\prime \prime} \mathrm{N}, 66^{\circ} 39^{\prime} 39.02^{\prime \prime} \mathrm{E}$ \\
\hline
\end{tabular}

\subsection{Vegetation Sampling and Chemical Analysis}

Three vegetation sites were chosen from the various degrees of vegetation covering to determine the plant parameters. The distance among the sampling sites were $1 \mathrm{~km}$. Each site was done with three replicates within a distance of $100 \mathrm{~m}$, depending on the degree of vegetation coverage (sparse, middle and dense). A total of nine plots were sampled (Figure 1, Table 1).

The coordinates of each subplot were taken using Global Positioning System (GPSGarmin GPS 12 XL 12 channel). Vegetation parameters were measured monthly from all of the nine plots during 2008-2010, including plant composition, above-ground biomass, cover, density, foliar chlorophyll, and carotenoid content.

The content of chlorophyll $a, b$ and carotenoids in the dominant species $A$. diffusa was detected using the Spectrophotometer (SF-26) after 100\% acetone extraction through the Wettstein method [26]. Geo-botanical descriptions were conducted on a 10 $\mathrm{m} \times 10 \mathrm{~m}$ transect plot, with three replicates conducted for all nine plots. The total number of each subshrub species within the $100 \mathrm{~m}^{2}$ plot was split into three classes (big, medium, small), based on the plant height and diameter, and three representative plants were harvested and separated into perennial wood and annual green components. To obtain the total biomass of each subplot, the density and biomass data were combined. The cover of each individual subshrub was determined from a $10 \mathrm{~m}$ line intercept along the four edges of the $10 \mathrm{~m} \times 10 \mathrm{~m}$ plot. The above-ground ephemeral biomass and ephemeroid was evaluated within $50 \mathrm{~cm} \times 10 \mathrm{~cm}$ frame quadrates, which were randomly distributed within the five replicates. All of the plant parameters were measured in a fresh way.

\subsection{Remote Sensing and Image Processing}

Time series Landsat TM5 images were acquired from United States Geological Survey (USGS) and Earth Resources Observation and Science (EROS) Center (http://earthexplorer.usgs.gov/). The study area was covered with the path/row of $156 / 32$ and $155 / 32$, and the spatial resolution of the Landsat image is $30 \mathrm{~m}$ with a swath 
width of $185 \mathrm{~km}^{2}$ (Table 2). A total of 25 images were selected depending on acquisition time and cloud cover for the three seasons (spring, summer, autumn) during the period of 2008 to 2010 (Table 2). All the images were processed according to the following stages: 1) The six bands (band 1, band 2, band 3, band 4, band 5, and band 7, with wavelength ranges from 0.45 to $0.52 \mu \mathrm{m}, 0.52$ to $0.60 \mu \mathrm{m}, 0.63$ to $0.69 \mu \mathrm{m}, 0.76$ to $0.90 \mu \mathrm{m}, 1.55$ to $1.75 \mu \mathrm{m}$, and 2.08 to $2.35 \mu \mathrm{m}$, respectively) were stacked together; 2) The images were converted to the BIL format; 3) Atmospheric correction was conducted using ActPro50 software; 4) The NDVI was calculated from the atmospherically corrected images using the following formula: (Band4 - Band 3$) /($ Band $4+$ Band 3$)$.

Finally, for each of the ground sample points (Table 1 ) the NDVI values were obtained and used in the further analysis.

\subsection{Statistical Analysis}

The experimental design consisted of three sites with three replicates. One-way ANOVA and the least significance difference $(L S D)$ test were applied to check the significance of the differences using SPSS 19.0 software. The Pearson's correlation test was also performed to check the relationships among the NDVI values, vegetation parameters, and soil and climate indicators during the plant growing season. The differences were considered significant if $P<0.05$. The figures were generated using Sigma Plot 10.0 (Aspire Software Intl. Ashburn, VA, USA).

\section{Results and Discussion}

\subsection{Dynamics of Vegetative Cover, Density and Above-Ground Biomass}

The dominant sagebrush $A$. diffusa develops above-ground components from late February to early June, with the entire vegetation cycle lasting for 230 - 237 days [7]. During the three study years (2008-2010), the mean cover of $A$. diffusa was lower (16\% $26 \%)$ in the spring season than in summer $(24 \%-37 \%)$ or autumn $(29 \%-40 \%)$ (Figures 4(a)-(c)). In 2009, the vegetation cover was slightly higher than that of 2008

Table 2. Dates of Landsat Thematic Mapper (TM5) images used in this study.

\begin{tabular}{cccc}
\hline Seasons & & Image date & \\
\hline Spring & $2008.04 .28^{* *}$ & $2008.05 .05^{*}$ & $2008.05 .30^{* *}$ \\
Summer & $2008.07 .01^{*}$ & $2008.07 .24^{* *}$ & $2008.08 .09^{*}$ \\
Autumn & $2008.09 .26^{*}$ & $2008.10 .05^{* *}$ & $2008.10 .12^{\star}$ \\
Spring & $2009.03 .21^{*}$ & $2009.04 .22^{*}$ & $2009.05 .08^{*}$ \\
Summer & $2009.06 .09^{* *}$ & $2009.06 .25^{*}$ & - \\
Autumn & $2009.09 .13^{*}$ & $2009.10 .08^{* *}$ & $2009.11 .16^{*}$ \\
Spring & $2010.04 .18^{* *}$ & $2010.04 .25^{*}$ & $2010.05 .11^{*}$ \\
Summer & $2010.07 .07^{* *}$ & $2010.07 .30^{*}$ & - \\
Autumn & $2010.09 .09^{* *}$ & $2010.10 .18^{*}$ & $2010.11 .12^{* *}$ \\
\hline
\end{tabular}

“*” represents Path 156/Row 32, “**” represents Path 155/Row 32 


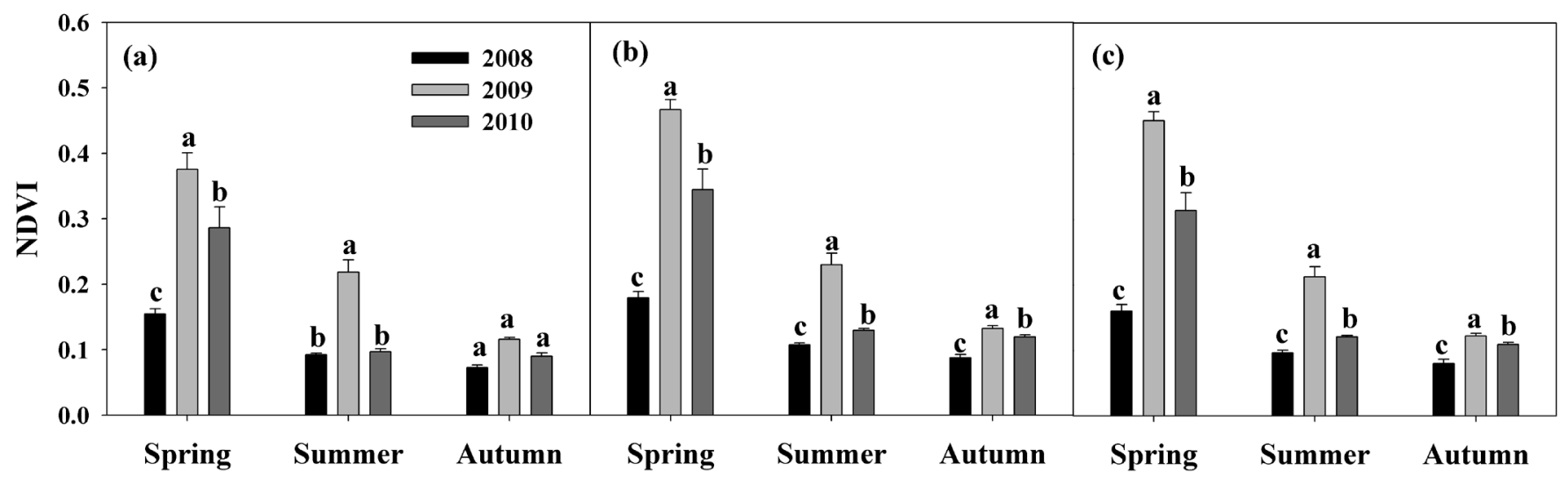

Figure 3. Seasonal dynamics of NDVI in the three study sites in 2008-2010. The data were shown as (a)-site first, (b)-site second, (c)-site third. Different letters indicate significant differences in the same season among three years at $P<0.05$ level (ANOVA, LSD test).

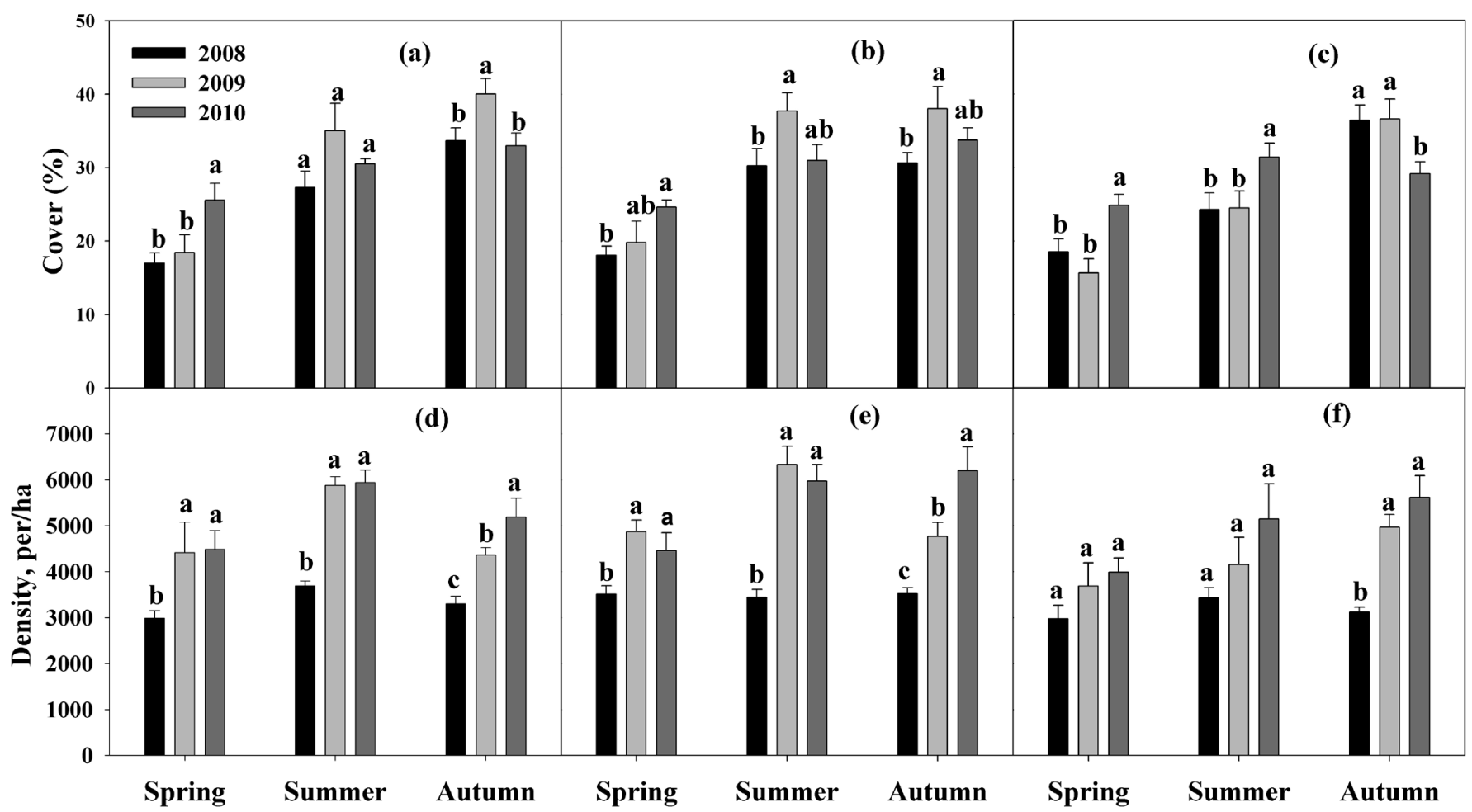

Figure 4. Seasonal dynamics of cover, and density of subshrub A. diffusa ((a)-site first, (b)-site second, (c)-site third). Error bars indicate SE $(\mathrm{n}=9)$. The different letters in the same column indicate significant differences among years at $P<0.05$ level (ANOVA, LSD test).

or 2010. This was due to more precipitation in the spring of 2009 (Figure 2). However, in the dry seasons (summer and autumn), the shortage of soil moisture has ceased vegetative period of annual and perennial ephemeroids communities. The density of $A$. diffusa increased from the wet season to the dry season, and the thickness decreased again at the end of autumn (Figures 4 (d)-(f)). This might be due to the fact that the sagebrush was heavily grazed by cattle in autumn but only slightly in summer, when the plants were sharply ephemeral and exuded a strong smell. The density and aboveground biomass of sagebrush $A$. diffusa were closely related in summer. Because of the 
wet spring, the first and second sites had higher total annual green above-ground vegetation biomass in 2009 (Figures 5(d)-(f)).

In the spring, $A$. diffusa + ephemeroides made up the total above-ground biomass (TAB), and the annual green above-ground biomass of $A$. diffusa + ephemeroides made up the green above-ground biomass (GAB) of vegetation. The GAB changed from 299 $\mathrm{kg} / \mathrm{ha}$ to $739 \mathrm{~kg} / \mathrm{ha}$ and the $\mathrm{TAB}$ changed from $991 \mathrm{~kg} / \mathrm{ha}$ to $2111 \mathrm{~kg} / \mathrm{ha}$ in spring, while in summer and autumn, TAB was consisted solely of $A$. diffusa (Figures 5(d)-(f)).

The annual green above-ground biomass of $A$. diffusa $\left(\mathrm{GAB}_{\mathrm{A}}\right)$ was $272-617 \mathrm{~kg} / \mathrm{ha}$ in spring, which increased to $392-1128 \mathrm{~kg} / \mathrm{ha}$ in summer but decreased to $175-762$ $\mathrm{kg} / \mathrm{ha}$ in autumn. The total above-ground biomass of $A$. diffusa $\left(\mathrm{TAB}_{\mathrm{A}}\right)$ was measured at $864-1958 \mathrm{~kg} / \mathrm{ha}$ in spring, and $1049-2675 \mathrm{~kg} / \mathrm{ha}$ and $834-2259 \mathrm{~kg} / \mathrm{ha}$ in summer and autumn, respectively (Figures 5(a)-(c)).

The $\mathrm{TAB}_{\mathrm{A}}$ and $\mathrm{GAB}_{\mathrm{A}}$ were higher in summer than in spring and autumn (Figures 5(a)-(c)). A. diffusa was found throughout the entire vegetation growing season, while the ephemeroids community (mainly $P$. bulbosa and $C$. pachystylis) was dominant during spring and ceased growing in summer (Figures $5(\mathrm{~d})-(\mathrm{f})$ ). Therefore, in summer and autumn, the NDVI indicators were represented only by $A$. diffusa. Only in spring was NDVI represented by ephemeroids and $A$. diffusa together.

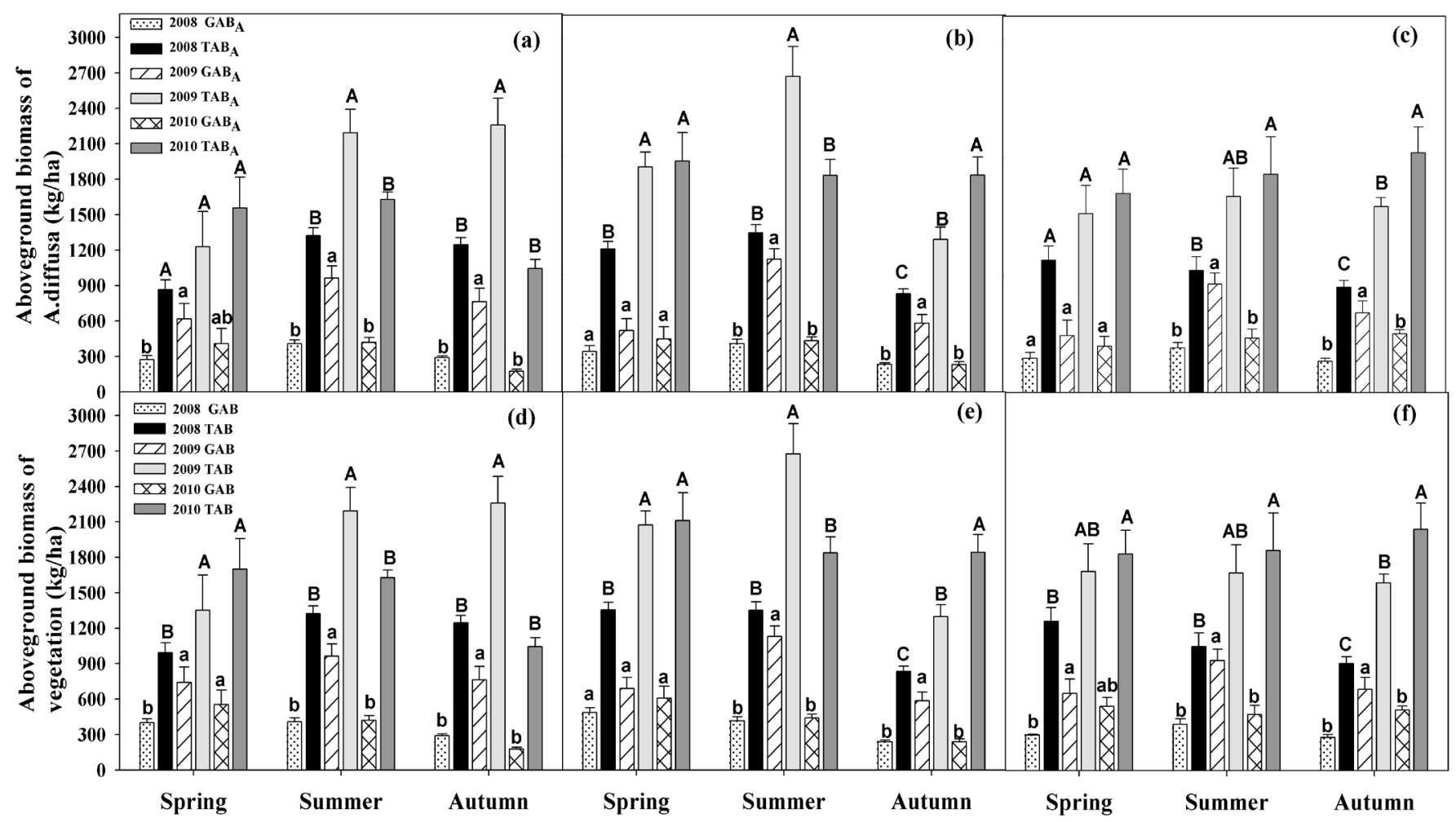

Figure 5. Seasonal dynamics of $\left(\mathrm{GAB}_{\mathrm{A}}\right)$ annual green and $\left(\mathrm{TAB}_{\mathrm{A}}\right)$ total aboveground biomass of subshrub $A$. diffusa in the three study sites ((a)-site first, (b)-site second, (c)-site third) and (GAB) total annual green and (TAB) total aboveground biomass of vegetation ((d)-site first, (e)-site second, (f)-site third). All aboveground biomass was measured at fresh weight. Error bars indicate SE ( $\mathrm{n}=9$ ). The different capital letters in the same column indicate significant differences in total biomass among years and lowercase letters stand for significant differences in green parts, at $P<0.05$ level (ANOVA, LSD test). 


\subsection{Leaf Pigments of Dominants and Connectivity with Environmental Factors}

Chlorophyll and carotenoid content of $A$. diffusa varied with climate conditions. The contents of chlorophyll of the three sites were $0.81-0.93 \mathrm{mg} / \mathrm{g}$ in spring, $0.91-1.14$ $\mathrm{mg} / \mathrm{g}$ in summer, and $0.44-0.80 \mathrm{mg} / \mathrm{g}$ in autumn. Accordingly, the carotenoid content was $0.21-0.33 \mathrm{mg} / \mathrm{g}$ in spring, -0.01 to $0.04 \mathrm{mg} / \mathrm{g}$ in summer, and $0.13-0.16$ in autumn, changing with the growing seasons (Table 3 ). The foliar chlorophyll and aboveground green biomass are main potential productivities of vegetation, and moreover, these factors are related to the photosynthetic activity of plants. Both indicators play an important role in the balance of the ecosystem, in areas such as regulation of climate, carbon storage, and sequestration of potential productivities of vegetation. Our results have shown significant positive correlation between chlorophyll and green aboveground biomass in the growing seasons $(P<0.05)$; moreover, significant positive correlation between chlorophyll and temperature (Mean Air Temperature MAT) has also been demonstrated $(P<0.05)$ (Table 4$)$.

\subsection{Seasonal and Inner-Annual Dynamics of Climate, Soil Indicators and Degradation Assessment}

The annual rainfall plays a key role in plant regeneration, survival, and the function of arid and semi-arid ecosystems [27]. In the study area, most precipitation occurs in spring, while summer and autumn are very dry. Precipitation is the most important influencing factor for plant growth and vegetation coverage. As soil structure is loam and soil layer is not deep, soil cannot hold much moisture for a long time. Higher precipitation together with lower temperature, and hence, lower potential evapotranspiration rates in meadow steppe would favor higher a precipitation-use efficiency and ANPP [28].

Table 3. Seasonal dynamics of foliar chlorophyll (CHL), carotenoids (CAR), of subshrub A. diffusa in the three study sites. Values are mean $\pm \mathrm{SE}(\mathrm{n}=3)$. The different letters in the same column indicate significant differences among years at $P<0.05$ level (ANOVA, $L S D$ test).

\begin{tabular}{|c|c|c|c|c|c|c|c|}
\hline \multirow[b]{2}{*}{ sites } & \multirow[b]{2}{*}{ years } & \multicolumn{3}{|c|}{$\mathrm{CHL}(\mathrm{mg} / \mathrm{g})$} & \multicolumn{3}{|c|}{$\mathrm{CAR}(\mathrm{mg} / \mathrm{g})$} \\
\hline & & spring & summer & autumn & spring & summer & autumn \\
\hline & 2008 & $0.91 \pm 0.02 \mathrm{a}$ & $0.96 \pm 0.22 \mathrm{a}$ & $0.76 \pm 0.23 a$ & $0.24 \pm 0.09 a$ & $0.01 \pm 0.05 a$ & $0.15 \pm 0.06 \mathrm{a}$ \\
\hline \multirow[t]{3}{*}{ a-site } & 2009 & $0.89 \pm 0.04 a$ & $0.99 \pm 0.25 a$ & $0.74 \pm 0.22 \mathrm{a}$ & $0.21 \pm 0.10 \mathrm{a}$ & $0.02 \pm 0.01 \mathrm{a}$ & $0.16 \pm 0.06 \mathrm{a}$ \\
\hline & 2010 & $0.81 \pm 0.04 a$ & $0.91 \pm 0.13 a$ & $0.44 \pm 0.10 \mathrm{a}$ & $0.33 \pm 0.01 \mathrm{a}$ & $0.02 \pm 0.02 \mathrm{a}$ & $0.14 \pm 0.05 \mathrm{a}$ \\
\hline & 2008 & $0.92 \pm 0.04 a$ & $1.07 \pm 0.31 \mathrm{a}$ & $0.79 \pm 0.20 \mathrm{a}$ & $0.23 \pm 0.08 \mathrm{a}$ & $-0.03 \pm 0.03 a$ & $0.15 \pm 0.06 \mathrm{a}$ \\
\hline \multirow[t]{3}{*}{ b-site } & 2009 & $0.93 \pm 0.05 a$ & $1.14 \pm 0.25 \mathrm{a}$ & $0.80 \pm 0.24 \mathrm{a}$ & $0.23 \pm 0.09 a$ & $0.02 \pm 0.03 a$ & $0.14 \pm 0.05 \mathrm{a}$ \\
\hline & 2010 & $0.88 \pm 0.03 a$ & $1.01 \pm 0.14 \mathrm{a}$ & $0.44 \pm 0.06 \mathrm{a}$ & $0.31 \pm 0.01 \mathrm{a}$ & $0.01 \pm 0.02 \mathrm{a}$ & $0.14 \pm 0.05 \mathrm{a}$ \\
\hline & 2008 & $0.93 \pm 0.02 \mathrm{a}$ & $1.00 \pm 0.26 \mathrm{a}$ & $0.80 \pm 0.22 \mathrm{a}$ & $0.23 \pm 0.09 a$ & $-0.01 \pm 0.05 a$ & $0.15 \pm 0.05 \mathrm{a}$ \\
\hline \multirow[t]{2}{*}{ c-site } & 2009 & $0.94 \pm 0.02 \mathrm{a}$ & $1.03 \pm 0.25 a$ & $0.79 \pm 0.21 \mathrm{a}$ & $0.22 \pm 0.08 \mathrm{a}$ & $-0.01 \pm 0.02 \mathrm{a}$ & $0.14 \pm 0.06 \mathrm{a}$ \\
\hline & 2010 & $0.84 \pm 0.03 a$ & $0.93 \pm 0.11 \mathrm{a}$ & $0.47 \pm 0.06 \mathrm{a}$ & $0.33 \pm 0.01 \mathrm{a}$ & $0.04 \pm 0.02 \mathrm{a}$ & $0.13 \pm 0.04 a$ \\
\hline
\end{tabular}


Table 4. Pearson's correlations among relative changes in mutual relations between natural components and time series of NDVI in foothill Artemisia-ephemeral rangeland, during growing time of three seasons (spring, summer, autumn) in three years (2008-2010). NDVI-normalized difference vegetation index and all of plant parameters were measured fresh. GAB, total annual green aboveground biomass of vegetation $(\mathrm{kg})$; TAB, total aboveground biomass of vegetation $(\mathrm{kg}) ; \mathrm{GAB}_{\mathrm{A}}$, annual green aboveground biomass of subshrub $A$. diffusa (kg); $\mathrm{TAB}_{\mathrm{A}}$, total aboveground biomass of subshrub A. diffusa (kg); CHL, foliar chlorophyll (mg/g); CAR, carotenoid (mg/g); PC, cover (\%); DEN, density of dominant subshrub $A$. diffusa (indiv. per/ha);SM, soil moisture (\%); $\mathrm{SN}$, soil changeable nitrogen ( $\mathrm{NO}_{3}^{-}$), $(\mathrm{mg} / \mathrm{kg}), \mathrm{SP}$, seasonal precipitation $(\mathrm{mm})$, AHmin, minimum air humidity $(\%)$, MAT, mean air temperature $\left({ }^{\circ} \mathrm{C}\right)$.

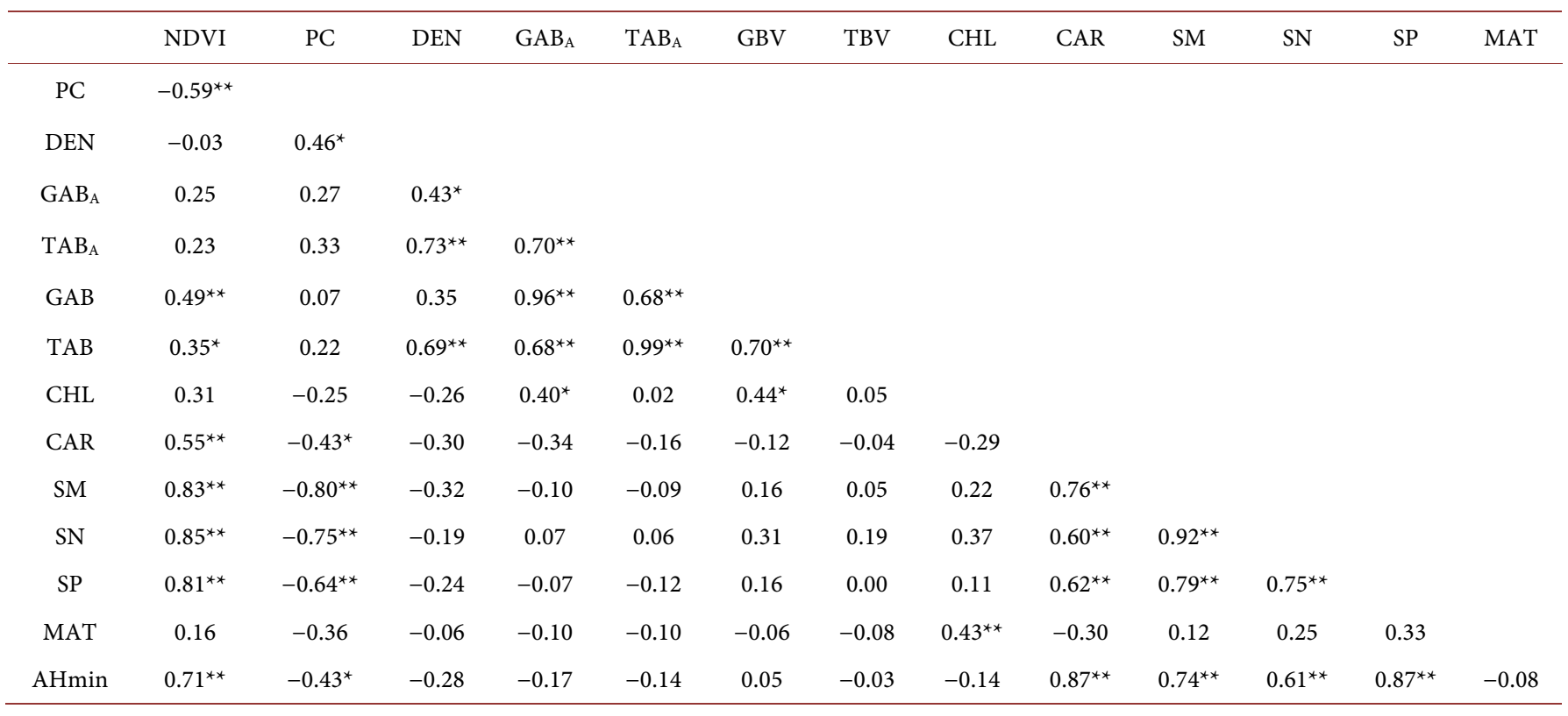

${ }^{*}$ Correlation is significant at the 0.01 level (2-tailed); ${ }^{*}$ Correlation is significant at the 0.05 level (2-tailed).

Soil moisture is one of the major restrictive factors for vegetation growth and is significantly correlated with the NDVI indicators in semi-arid and arid rangeland. However, rainfall is not the dominating limiting factor for grassland restoration, while soil moisture is more important than rainfall for plant growth [3]. In the study area, loamy soil structure was pervasive. Therefore the drying process of soil surface was accelerated and precipitation was highly related with soil moisture. Moreover, long-term grazing exclusion would improve soil moisture in the rangeland of the semi-arid regions. Soil water availability is critical to plant survival, development, and ultimate productivity, and precipitation is a major natural source for soil moisture in the semi-arid grassland [29]. Changes in the seasonal dynamics of soil moisture in the $0-40 \mathrm{~cm}$ layer were apparent in spring as the moisture was measured at $14.1 \%-19.7 \%$, increasing from $2.1 \%$ to $4.8 \%$ in summer and autumn (Figures 6(d)-(f)). Our results show that in the study area 5\% - 8\% soil moisture limited ephemeroid vegetative growth (Figures 3(d)-(f), Figures 5(d)-(f)). Overgrazing factors were also effective in decreasing green coverage, and both soil moisture and overgrazing influenced the dynamics of the NDVI. Green leaf area index, green biomass, and vegetation coverage are useful indicators of the health of rangeland, which can be used to analyze the status of the ecosystem health and define the degree of land degradation [30]. In spring, the NDVI was higher (Figures $3(\mathrm{a})-(\mathrm{c})$ ) than in other seasons, as the lands were covered with annual and perennial 


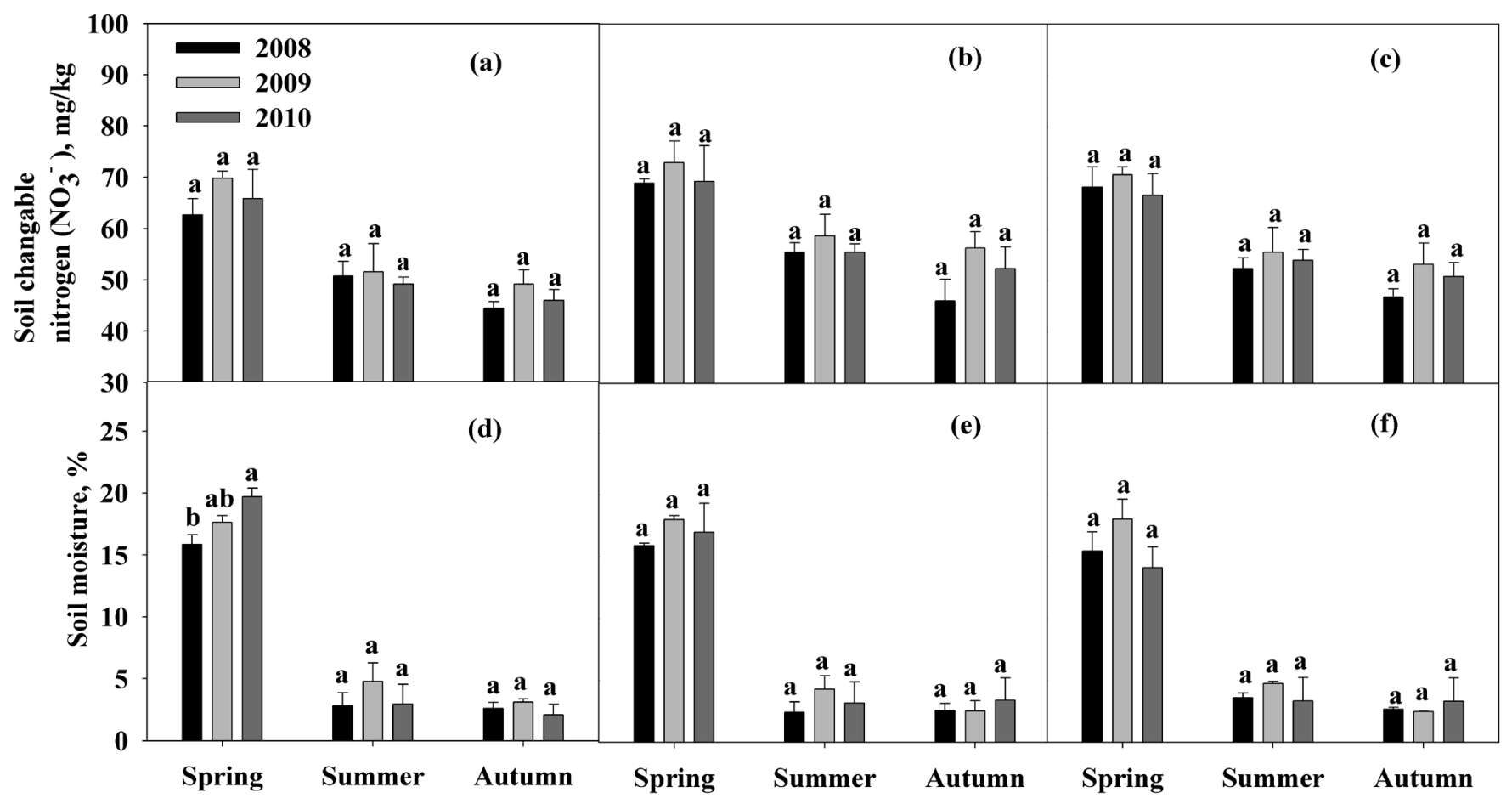

Figure 6. Seasonal dynamics of soil moisture (SM), ((a)-site first, (b)-site second, (c)-site third) and soil changeable nitrogen (SN), ((d)-site first, (e)-site second, ( $\mathrm{f}$-site third). Error bars indicate SE $(\mathrm{n}=3)$. The different letters in the same column indicate significant differences among years at $P<0.05$ level (ANOVA, LSD test).

ephemeroids in this season. Moreover, higher NDVI values in the spring were evident in other years as well, as in the spring, the land was covered by a carpet of ephemeroids. Therefore, the spring images cannot demonstrate the degradation trend when the land was uniformly covered with the ephemeroid community. Meanwhile, the summer and autumn satellite images indicated a clearer degradation of dominant sagebrush (Figure $1)$.

The NDVI was higher in the spring of 2009 than in other seasons, indicating the amount of precipitation was greater than in other growing seasons (Figure 2). In that same season, A. diffusa and ephemeroids recovered faster and grew taller than before. However, precipitation, nutrients, and soil physical properties seldom affect spring phenology, while the temperature is very significant [31]. Well-established relationships between climate conditions and vegetation productivity have been found [32] [33].

Soil moisture and temperature were important factors for inorganic nitrogen pools and net nitrogen mineralization of soil [34] [35] [36]. The amount of soil changeable nitrogen $\left(\mathrm{NO}_{3}^{-}\right)$in the $0-40 \mathrm{~cm}$ layer was measured at 62.6 to $72.9 \mathrm{mg} / \mathrm{g}$ in spring, and grew from 44.4 to $58.7 \mathrm{mg} / \mathrm{g}$ in summer and autumn (Figures 6(a)-(c)). Overgrazing also impacts mineralization progress in grassland ecosystems [37]. Furthermore, freezing and thawing in winter and in early spring are reported as important events for soil inorganic nitrogen availability and net nitrogen mineralization [38] [39].

In the early growing season, soil moisture causes a lower $\mathrm{N}$ nitrification rate, and the existence of grazing decreases the annual cumulative $\mathrm{N}$ nitrification. We found that the 
wet season had promoted the nitrification process, which almost ceased after subsequent grazing (Figures $6(\mathrm{a})-(\mathrm{c})$ ). In contrast, the dry season greatly inhibited net $\mathrm{N}$ mineralization, and subsequently, soil microbial activity and plant growth [40]. Other factors impacting soil drying included air humidity, temperature, wind, and transpiration. The soil microbial activity is mostly stronger at elevated temperatures, while the impact is smaller at low temperatures [40]. The climate of summer and autumn in the study area was very dry, decreasing the nitrification process, evidenced by lower soil changeable nitrogen (Figures 6(a)-(c)).

\subsection{Relationships of Environment Indicators of Rangeland and NDVI}

High correlations between above-ground biomass and climatic factors, including precipitation and temperature, have been frequently reported [41] [42] [43]. Precipitation is a key climatic factor in controlling primary productivity in most arid ecosystems around the world. In growing seasons, highly positive significant correlations were found between the NDVI and precipitation $(\mathrm{r}=0.81, P<0.01)$ as well as was significantly related between the NDVI and the annual above-ground biomass of vegetation, $\mathrm{GAB}(\mathrm{r}=0.49, P<0.01)$. In the plant growing seasons, significant correlation of NDVI values with coverage of dominant Artemisia diffusa were found, caused by the soil moisture changes. Foliar chlorophyll and above-ground biomass were also vital for greenness and health of plants, and positive significant correlation between foliar chlorophyll and GAB $(\mathrm{r}=0.44, P<0.01)$ was also noted (Table 4$)$. Timing of precipitation is particularly important for grassland productivity [44]. Precipitation has influences on soil moisture that affects soil changeable nitrogen content. Water and $\mathrm{N}$ availability that govern species diversity, ANPP, and ecosystem stability are critical in semiarid grassland [45]. In this study, we have found positive relationships among the NDVI, soil moisture, and changeable nitrogen $(P<0.01)$ (Table 4$)$.

In the semi-arid ecosystem, vigor of plants and their productivity were related with climate and soil. We found chain correlations among plant, soil, and climate connection to eco-physiological indicators in the foothill rangeland, any of which may affect plant greenness. This may be the reason for inferring balance of rangeland environments, which enable us to use NDVI or other remote-sensing-based indicators to assess the health status of rangeland ecosystems. Our three years' monitoring of vegetation, soil, and physiological characteristics clearly demonstrate the chain correlations. The findings of this study are important and will further help in the studies of rangeland and environmental sustainability.

\section{Conclusion}

Many factors influencing the dynamics of plant productivity and soil parameters, such as soil moisture and precipitation, can be well-monitored using both ground measurements and satellite image data. All of these connections, particularly with NDVI in arid foothill rangeland, can offer access for monitoring and assessing vegetation coverage and potential productivity using remote sensing. The precipitation and soil moisture 
influenced both the seasonal and annual vegetation dynamics regulating plant photosynthetic pigments. Our findings will help decision makers providing detection tools to monitor the ecosystem balance of rangeland and the degradation effects from global climate change. If we use this information efficiently, these vegetation indices can be powerful tools for scaling a physiologically-based estimation of vegetation dynamics in the arid and the semi-arid foothill regions.

\section{Acknowledgements}

This study was supported by a grant from joint contribution between State Key Laboratory of Vegetation and Environmental Change, Institute of Botany, the Chinese Academy of Sciences and Laboratory of Environmental Problems, Samarkand State University and acknowledges funding of the CAS-TWAS President's Fellowship Program. We wish to acknowledge Mrs. Vera A. Onishchenko for helping of laboratory analysis. We also thank all the researchers who have given us help during the study.

\section{References}

[1] Han, J.G., Zhang, Y.J., Wang, C.J., Bai, W.M., Wang, Y.R., Han, G.D. and Li, L.H. (2008) Rangeland Degradation and Restoration Management in China. Rangeland Journal, 30, 233-239. https://doi.org/10.1071/RJ08009

[2] Bai, Y.F.B., Han, X.G., Wu, J.G., Chen, Z.Z. and Li, L.H. (2007) Positive Linear Relationship between Productivity and Diversity: Evidence from the Eurasian Steppe. Journal of Applied Ecology, 44, 1023-1034. https://doi.org/10.1111/j.1365-2664.2007.01351.x

[3] Jing, Z., Cheng, J. and Chen, A. (2013) Assessment of Vegetative Ecological Characteristics and the Succession Process during Three Decades of Grazing Exclusion in a Continental Steppe Grassland. Ecological Engineering, 57, 162-169. https://doi.org/10.1016/j.ecoleng.2013.04.035

[4] Jiang, G., Han, X. and Wu, J. (2006) Restoration and Management of the Inner Mongolia Grassland Require a Sustainable Strategy. AMBIO, 35, 269-270. https://doi.org/10.1579/06-S-158.1

[5] Paudel, K. P. and Andersen, P. (2010) Assessing Rangeland Degradation Using Multi Temporal Satellite Images and Grazing Pressure Surface Model in Upper Mustang, Trans Himalaya, Nepal. Remote Sensing of Environment, 114, 1845-1855. https://doi.org/10.1016/j.rse.2010.03.011

[6] Chartier, M.P., Rostagno, C.M. and Videla, L.S. (2013) Selective Erosion of Clay, Organic Carbon and Total Nitrogen in Grazed Semiarid Rangelands of Northeastern Patagonia, Argentina. Journal of Arid Environments, 88, 43-49. https://doi.org/10.1016/j.jaridenv.2012.08.011

[7] Gintzburger, G., Toderich, K.N., Mardonov, B.K. and Mahmudov, M.M. (2003) Rangelands of the Arid and Semi-Arid Zones in Uzbekistan. CIRAD-ICARDA, Montpellier, 16-100.

[8] Nosyrov, M. (2003) Karnab Chul, Samarkand, Uzbekistan: Frame Work of Assessment Methodology. Proceedings of the Second International Workshop on Combating Desertification (SUMAMAD), Iran, UNESCO-MAB Drylands Series No.3.100-111.

[9] Rajabov, T. (2009) Ecological Assessment of Spatio-Temporal Changes of Vegetation in Response to Biosphere Effects in Semi-Arid Rangelands of Uzbekistan: Land Restoration Training Programme. Reykjavik, Iceland. 
http://www.unulrt.is/static/fellows/document/rajabov t.pdf

[10] Bloom, A.J., And, F.S.C.I. and Mooney, H.A. (2003) Resource Limitation in Plants-An Economic Analogy. Annual Review of Ecology \& Systematics, 16, 363-392.

https://doi.org/10.1146/annurev.es.16.110185.002051

[11] Gamon, J.A., Field, C.B., Roberts, D.A., Ustin, S.L. and Valentini, R. (1993) Functional Patterns in an Annual Grassland during an AVIRIS over Flight. Remote Sensing of Environment, 44, 239-253. https://doi.org/10.1016/0034-4257(93)90019-T

[12] Rouse, J.W., Haas, R.H., Schell, J.A. and Deering, D.W. (1974) Monitoring Vegetation Systems in the Great Plains with Erts. Nasa Special Publication, 351, 309.

[13] Justice, C.O., Townshend, J.R.G., Holben, B.N. and Tucker, C.J. (1985) Analysis of the Phenology of Global Vegetation Using Meteorological Satellite data. International Journal of Remote Sensing, 6, 1271-1318. https://doi.org/10.1080/01431168508948281

[14] Gibson, P.J., Power, C.H., Goldin, S.E. and Rudahl, K.T. (2000) Introductory Remote Sensing: Digital Image Processing and Applications. Routledge London, UK, 92-112.

[15] Beck, P.S.A., Atzberger, C., Høgda, K.A., Johansen, B. and Skidmore, A.K. (2006) Improved Monitoring of Vegetation Dynamics at Very High Latitudes: A New Method Using MODIS NDVI. Remote Sensing of Environment, 100, 321-334. https://doi.org/10.1016/j.rse.2005.10.021

[16] Blanco, L.J., Aguilera, M.O., Paruelo, J.M., and Biurrun, F.N. (2008) Grazing Effect on NDVI across an Aridity Gradient in Argentina. Journal of Arid Environments, 72, 764-776. https://doi.org/10.1016/j.jaridenv.2007.10.003

[17] Pettorelli, N., Vik, J.O., Mysterud, A., Gaillard, J.M., Tucker, C.J. and Stenseth, N.C. (2005) Using the Satellite-Derived NDVI to Assess Ecological Responses to Environmental Change. Trends in Ecology \& Evolution, 20, 503-510. https://doi.org/10.1016/j.tree.2005.05.011

[18] Lei. J. and Peters, A.J. (2003) Assessing Vegetation Response to Drought in the Northern Great Plains Using Vegetation and Drought Indices. Remote Sensing of Environment, 87, 85-98. https://doi.org/10.1016/S0034-4257(03)00174-3

[19] Hostert, P., Roder, A., Jarmer, T., Udelhoven, T. and Hill, J. (2001) The Potential of Remote Sensing and GIS for Desertification Monitoring and Assessment. Annals of Arid Zone, 40, 103-140.

[20] Star, J.L., Estes, J.E. and Mcgwire, K.C. (2010) Integration of Geographic Information Systems and Remote Sensing. Cambridge University Press, Cambridge.

[21] Rahmatullaev, A. (1991) Landscapes Ridge Aktau, Their Use Rational Economic and Protection. "FAN" Publisher, Tashkent, Uzbekistan, 7-80. (In Russian)

[22] Makmudovich, M. (2006) Country Pasture/Forage Resource Profiles for Uzbekistan. Food and Agriculture Organization of the United Nations (FAO) Crop and Grassland Service. http://www.fao.org/ag/AGP/AGPC/doc/Counprof/Uzbekistan/uzbekistan.htm

[23] Zokirov, P.K. (1971) Botanical Geography Piedmont of Kyzyl-Kum and Nuratau (Mountain) Range. "FAN" Publisher, Tashkent, Uzbekistan, 131-151. (In Russian)

[24] Burygin, V.A. (1976) The Vegetation Cover of Uzbekistan and Its Rational Use. "FAN" Publisher, Tashkent, Uzbekistan. (In Russian)

[25] Minayeff, V.G. (2001) Practical Work on Agrochemistry. Moscow State University Publisher, Moscow. (In Russian)

[26] Tretyakov, N.N. (1990) Practical Work on Plant Physiology. "Agropromizdat" Publisher, Moscow. (In Russian) 
[27] Ogle, K. and Reynolds, J.F. (2004) Plant Responses to Precipitation in Desert Ecosystems: Integrating Functional Types, Pulses, Thresholds, and Delays. Oecologia, 141, 282-294. https://doi.org/10.1007/s00442-004-1507-5

[28] Hu, Z., Yu, G., Fan, J., Zhong, H., Wang, S., and Li, S. (2010) Precipitation-Use Efficiency along a 4500-km Grassland Transect. Global Ecology \& Biogeography, 19, 842-851. https://doi.org/10.1111/j.1466-8238.2010.00564.x

[29] He, Y., Guo, X. and Si, B.C. (2007) Detecting Grassland Spatial Variation by a Wavelet Approach. International Journal of Remote Sensing, 28, 1527-1545. https://doi.org/10.1080/01431160600794621

[30] Zhang, C. and Guo, X. (2008) Monitoring Northern Mixed Prairie Health Using Broadband Satellite Imagery. International Journal of Remote Sensing, 29, 2257-2271. https://doi.org/10.1080/01431160701408378

[31] Sparks, T.H., Carey, P.D. and Combes, J. (1997) First Leafing Dates of Trees in Surrey between 1947 and 1996. London Naturalist, 76, 15-20.

[32] Andales, A.A., Derner, J.D., Ahuja, L.R. and Hart R.H. (2006) Strategic and Tactical Prediction of Forage Production in Northern Mixed-Grass Prairie. Rangeland Ecology \& Management, 59, 576-584. https://doi.org/10.2111/06-001R1.1

[33] Wu, C. and Chen, J.M. (2012) The Use of Precipitation Intensity in Estimating Gross Primary Production in Four Northern Grasslands. Journal of Arid Environments, 82, 11-18. https://doi.org/10.1016/j.jaridenv.2012.02.014

[34] Knoepp, J.D. and Swank, W.T. (2002) Using Soil Temperature and Moisture to Predict Forest Soil Nitrogen Mineralization. Biology \& Fertility of Soils, 36, 177-182. https://doi.org/10.1007/s00374-002-0536-7

[35] Sierra, J. (1997) Temperature and Soil Moisture Dependence of N Mineralization in Intact Soil Cores. Soil Biology \&Biochemistry, 29, 1557-1563. https://doi.org/10.1016/S0038-0717(96)00288-X

[36] Wang, C., Wan, S., Xing, X., Zhang, L. and Han, X. (2006) Temperature and Soil Moisture Interactively Affected Soil Net N Mineralization in Temperate Grassland in Northern China. Soil Biology \& Biochemistry, 38, 1101-1110. https://doi.org/10.1016/j.soilbio.2005.09.009

[37] Shan, Y., Chen, D., Guan, X., Zheng, S., Chen, H., Wang, M. and Bai, Y. (2011) Seasonally Dependent Impacts of Grazing on Soil Nitrogen Mineralization and Linkages to Ecosystem Functioning in Inner Mongolia Grassland. Soil Biology \& Biochemistry, 43, 1943-1954. https://doi.org/10.1016/j.soilbio.2011.06.002

[38] Brooks, P.D., Williams, M.W. and Schmidt, S.K. (1998) Inorganic Nitrogen and Microbial Biomass Dynamics Before and during Spring Snowmelt. Biogeochemistry, 43, 1-15. https://doi.org/10.1023/A:1005947511910

[39] Zhao, H., Zhang, X., Xu, S., Zhao, X., Xie, Z. and Wang, Q. (2010) Effect of Freezing on Soil Nitrogen Mineralization under Different Plant Communities in a Semi-Arid Area during a Non-Growing Season. Applied Soil Ecology, 45, 187-192. https://doi.org/10.1016/j.apsoil.2010.04.002

[40] Borken, W. and Matzner, E. (2009) Reappraisal of Drying and Wetting Effects on C and N Mineralization and Fluxes in Soils. Global Change Biology, 15, 808-824. https://doi.org/10.1111/j.1365-2486.2008.01681.x

[41] Derner, J.D., Hickman, K.R. and Polley, H.W. (2011) Decreasing Precipitation Variability Does Not Elicit Major Aboveground Biomass or Plant Diversity Responses in a Mesic Rangeland. Rangeland Ecology \& Management, 64, 352-357. https://doi.org/10.2111/REM-D-10-00121.1 
[42] Fang, J., Piao, S., Zhou, L., He, J., Wei, F., Myneni, R.B., Tucker, C.J. and Tan, K. (2005) Precipitation Patterns Alter Growth of Temperate Vegetation. Geophysical Research Letters, 32, 365-370. https://doi.org/10.1029/2005GL024231

[43] Guo, Q., Hu, Z., Li, S., Li, X., Sun, X. and Yu, G. (2012) Spatial Variations in Aboveground Net Primary Productivity along a Climate Gradient in Eurasian Temperate Grassland: Effects of Mean Annual Precipitation and Its Seasonal Distribution. Global Change Biology, 18, 3624-3631. https://doi.org/10.1111/gcb.12010

[44] Craine, J.M., Nippert, J.B., Elmore, A.J., Skibbe, A.M., Hutchinson, S.L. and Brunsell, N.A. (2012) Timing of Climate Variability and Grassland Productivity. Proceedings of the National Academy of Sciences of the United States of America, 109, 3401-3405. https://doi.org/10.1073/pnas.1118438109

[45] Bai, Y., Han, X., Wu, J., Chen, Z., and Li, L. (2004) Ecosystem Stability and Compensatory Effects in the Inner Mongolia Grassland. Nature, 431, 181-184.

https://doi.org/10.1038/nature02850

Submit or recommend next manuscript to SCIRP and we will provide best service for you:

Accepting pre-submission inquiries through Email, Facebook, LinkedIn, Twitter, etc. A wide selection of journals (inclusive of 9 subjects, more than 200 journals)

Providing 24-hour high-quality service

User-friendly online submission system

Fair and swift peer-review system

Efficient typesetting and proofreading procedure

Display of the result of downloads and visits, as well as the number of cited articles

Maximum dissemination of your research work

Submit your manuscript at: http://papersubmission.scirp.org/

Or contact oje@scirp.org 